\title{
Strategy to Improve Scientific and Technological Innovation Capacity
}

\author{
Li Yang ${ }^{1, *}$ and Feng Qian ${ }^{2}$ \\ ${ }^{1,2}$ College of Architecture \& Urban Planning, Tongji University, Key Laboratory of Ecology and Energy Saving Study of Dense \\ Habitat (Tongji University), Ministry of Education, Shanghai, P. R. China
}

${ }^{*}$ Corresponding author

\begin{abstract}
Human beings are the key of technical innovation, therefore higher requirements is necessary to achieve ambitious goal of improving scientific and technological innovation capacity.This article puts forwards six required human qualities based on the development of society and some cases. Then, some key abilities and qualities talents should possess are pointed out. Finally, suggestions about how to improve innovation quality of talents are presented from four aspects: creativity training, continuous education, incentive strategies and innovative inputs.All analysis would make scientific and technological innovation smoother in the direction of being beneficial to human beings and society.
\end{abstract}

Keywords-scientific and technological innovation; required human qualities; innovative talents

\section{INTRODUCTION}

Science and technology (S\&T) have promoted the progress of human society and their rapid development has for opened up a broader space for social productivity development and human civilization. The progress of S\&T has not only vigorously promoted the development of economy and society, but also has created enormous material and spiritual wealth for human being. In today's society of knowledge-driven society, the development of S\&T has become the important force to impact national development, at the same time, it is well recognized that the development of S\&T is greatly determined by talents and professionals [1]. Thus, the cultivation of quality-oriented talents in the field of S\&T is crucial to improve national economy, culture, science, technology, and even human society.

\section{REQUIRED QUALITIES OF S\&T INNOVATIVE TALENTS}

Innovation is a conceptual process, which is characterized by new thinking, new creation, new invention and even new description of a well-known thing. In general, innovation should be an initiative means to propose some ideas that are different from normal and ordinary thoughts based on our current existing thinking modes, existing knowledge and materials. In a specific environment, it can also be interpreted as a type of improved or created new things, methods, element, path, environment and behavior to satisfied idealized needs and the needs of society. However, the understanding and comprehension into innovation is a dynamic developing process [2]. From the evolution of innovation description (as shown in Table I), it is clearly seen that the concept of innovation is complex and various.

TABLE I. THE DESCRIPTION OF INNOVATION IS DIFFERENT PERIODS

\begin{tabular}{|c|c|c|l|}
\hline Period & Scholars & Theory & \multicolumn{1}{c|}{ Description } \\
\hline 1912 & $\begin{array}{c}\text { Joseph A. } \\
\text { Schumpeter }\end{array}$ & $\begin{array}{c}\text { Innovation } \\
\text { Theory }\end{array}$ & $\begin{array}{l}\text { Innovation is a new } \\
\text { technology or new invention, } \\
\text { which is applied in business } \\
\text { for the first time, and it is a } \\
\text { special stage in the process } \\
\text { of the economy. }\end{array}$ \\
\hline 1960s $~$ & $\begin{array}{c}\text { Schmookler } \\
\text { Jacob }\end{array}$ & $\begin{array}{c}\text { Simple } \\
\text { Linear } \\
\text { Analysis }\end{array}$ & $\begin{array}{l}\text { The origin of innovative } \\
\text { activities: Technology } \\
\text { driving or Market demand? }\end{array}$ \\
\hline 1970 s $~$ & $\begin{array}{c}\text { Rosenberg } \\
\text { Nathan \& } \\
\text { Richard R. } \\
\text { Nelson }\end{array}$ & $\begin{array}{c}\text { Link } \\
\text { relationshi } \\
\text { p, Linear } \\
\text { Analysis }\end{array}$ & $\begin{array}{l}\text { Innovation is a special and } \\
\text { complex process that } \\
\text { contains many interactions } \\
\text { and feedbacks. }\end{array}$ \\
\hline \multirow{2}{*}{ 1980s } & $\begin{array}{c}\text { Richard R. } \\
\text { Nelson \& } \\
\text { Lundvall, } \\
\text { Bengt-Åke, } \\
\text { ed. }\end{array}$ & $\begin{array}{c}\text { Systematic } \\
\text { Analysis }\end{array}$ & $\begin{array}{l}\text { Innovation is a systematic } \\
\text { process and a complex } \\
\text { mutual process, which } \\
\text { includes interplay and } \\
\text { interaction between the main } \\
\text { bodies of innovation. }\end{array}$ \\
\hline
\end{tabular}

In the 21st century's knowledge-oriented society, its improvement and impact on human beings will be further understood. S\&T innovation is a process related to economy and technology, and it is a joint development product based on technological progress and innovative application. When it comes to economic benefits, it would be a commercial operating activity with the features of high risk and high reward [3]. Thus, demand-oriented and people-oriented innovation would be a complex activity that subjected to interaction of social demand, innovation subject and innovation elements in our society. Against this backdrop, in order to meet the requirements of S\&T and its development, it is necessary to rethink the position of innovative talents and to build a suitable innovative talent training system for social development [4].

Modern S\&T development needs modern innovative talents, who not only have reasonable and higher technical knowledge, but also grasp brief knowledge of economy and management. Namely, they should possess the combination spirits of both social humanities and modern science. In S\&T innovation activities, based on some challenges and opportunities, an S\&T innovative talent can make full use of their own resources with reasonable and efficient method, to analyze and solve problems and further make feedback to society. S\&T innovative talents 
should possess several abilities, including creative capital, good moral quality, wide range of knowledge, innovative ability, personal reaction capacity, collaborative capability etc. S\&T innovative talents training process and required qualities are presented in Figure I.

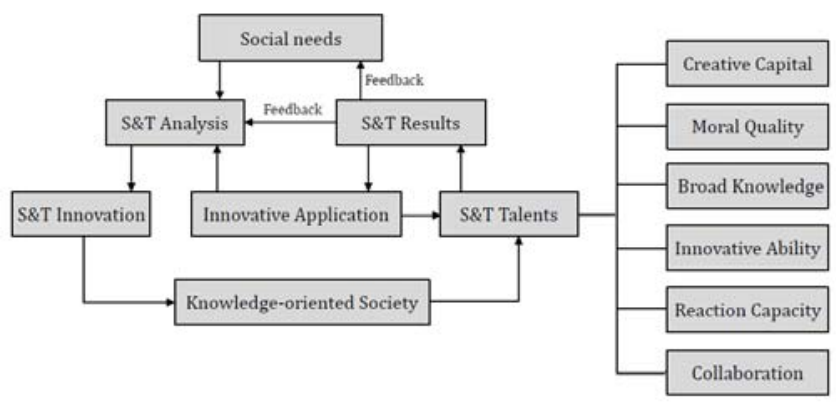

FIGURE I. TRAINING PROCESS AND REQUIRED QUALITIES OF S\&T TALENTS

\section{A. Creative Capital}

At present, people have clearly realized that the real wealth in future economic activities is thought, knowledge, skill, talents and creativity. It is proved from the phenomenon that creative industries are quite hot from various developed countries to developing countries. Creative capital is the entire integration of ideal spirit of creative people and material idea of investors, and this should be the ideal process of sustainable economy and society. In the 1990s, the concept of creativity is introduced into British cultural policy. Additional, the Creative Industries Mapping Document issued in 1998 presented scopes of creative economy and creative industries. Human beings are main bodies of creative capital, so it is required for S\&T innovative talents [5].

British is the birthplace of creative economy, at the same time, it is one of the most favored countries all over the world. This is resulted from the policies and measures, including creative training and enterprise education. It is estimated that the number of creative employers in 2012 was about 1.7 million, whose economic output in Britain GDP had gone beyond manufacturing industry. In England, creative sector in various fields, from film to fashion, games to software, advertisements to architecture, with about 111 US dollars, drives economic growth and supports jobs across England, Northern Ireland, Scotland and Wales [6]. The development of creative industries relies on the overall upgrades of national innovative qualities and their performance of group creativities. Thus, it is necessary to adopt the policy of education training to give S\&T innovative talent an advantage in terms of creative capital, which is thought as a deep foundation for sustainable development of British creative industries.

The creative capital of S\&T innovative talents has brought a great deal of benefits to England and several counties all over the world have actively followed this strategy. Australia, China, Japan, South Korea and Singapore and other countries have promoted the development of creative industries and creative economy to the level of administrative policy and national intellectual property, even creative industries have developed as the national pillared industry in UK and US [7]. Therefore, from the trend of creative economy, creative capital should be one of the most important required qualities of S\&T innovative talents.

\section{B. Moral Qualities}

Good moral quality is the integral character of people's business, human civilization and its sustainable development. In terms of moral, it refers to people's good inherent basis, which manifests public spirit and social responsibility, shows as a correct outlook on life and values, and the concern for people, nation and state at a high level. Since the 20th century, S\&T innovation has made scientific technology develop at a rapid speed. It not only has brought the rapid development of economy and society, but also has caused a series of negative effects, such as environmental pollution, energy crisis and ecological destruction. Thus, if there is no certain support of moral quality, the S\&T will lose value orientation [8]. Only by natural science knowledge without any attention on moral quality education, a great negative effect may occur when S\&T innovation drives the development of human society.

These problems represent a higher moral quality demands for S\&T innovative talents. The aim of moral quality education for innovative talents is to ensure them undertake social responsibility. From the view of global and society, they should have a good understanding of what their impact on human society and nature are and what their professional and moral responsibility are. As S\&T innovative talents, they must understand the way they will influence social and natural environment and they have to know the way to understand and grasp moral standards as well as relevant laws and regulations. They are equipped with basic moral inferential capability and know how to tell right from wrong.

S\&T innovative talents, as the representative of the most advanced productivity level of human society, deserve to be admired and respected. However, as this special group, they will be affected by various social forces and temptation, especially under the condition of free economy with a variety of social values, so they should have good moral quality. In S\&T innovative innovation activities, they not only consider the short-term economic benefits of innovation, but also consider long-term and fundamental interests for human beings. Some innovative achievements will give a part of group an advantage of convenience, but a factor that whether it is beneficial to the progress of the society and nation, even whether it will influence the harmony of nature and human beings should be attached importance [9]. Only when these become overall assessment indicators of innovation activities, innovative talents can truly make S\&T innovation benefit to our human beings, and will be inexhaustible driving force of social and human progress.

Moral quality education is conducive to improve S\&T innovative talents' quality. In terms of professional ethnics, moral education provides a way to improve and develop good ones, so this means only those who have the right and appropriate professional ethics, innovative talents can effectively serve the society and realize their social value. While in the perspective of personal all-round development, an 
important goal of moral education is to help innovative talents fulfill them, which means that these talents not only have the scientific knowledge and skills, but also the spirit and quality of civilization.

Moral education is helpful to cultivate the innovation ability and cultivate innovative methods. Moral quality education allows innovative talents to think in a scientific way and inspire their innovative spirit, so that they can actively put themselves into innovative practice. Moral education provides a suitable environment to them to develop their innovation ability. On the one hand, moral education systems in a country allow students to realize the importance of innovation and realize that they should respect for the creative talents and their achievements; on the other hand, it provides an appropriate social environment with good brilliant public opinion and spiritual power of discovery and development. Therefore, the theme of creation and invention will be a part of innovation plan together with other positive action and even all positive elements. That is also the reason why innovative talents think that their creative work is one of important parts of their life.In general, it is obvious that good moral quality should be a good character of S\&T innovative talents. Thus, in their daily life, it is necessary to guide them to improve their humanistic concern and let them know that their success comes from society, so as to arouse their feeling of gratitude and transfer them to social behaviors. This will increase social and environmental responsibility of S\&T talents.

\section{Broad Knowledge}

Cultural knowledge plays a vital important role in improving people's comprehensive quality and creative capacity. It is thought as the ladder of human progress and the most important resources of S\&T innovation. A person who can obtain profound achievements tends to be knowledgeable, and that is also a shared characteristic of Nobel Prize winner. As for the S\&T innovative talents, broad knowledge should also be a basic characteristic, which is interpreted as high academic level, professional and technical knowledge and broad scope of knowledge. According to a survey about 442 Nobel Prize winners, all of them have a degree of bachelor or above and $90.3 \%$ of them hold the degree of doctor of philosophy. Thus, education background would be a significant symbol to show their profound and solid cultural knowledge. The statistics of these Nobel Prize winners has obviously showed that their achievements have a good relationship with their broad knowledge.

It is stressed that if talents do not work hard to let ourselves master broad knowledge, the idea about being high-level S\&T innovative talents will be only a type of fashionable talk or the fantasy in the air . That is not only because different disciplines are mutual influenced and infiltrated, but also because that only the integral application of Interdisciplinary knowledge can these talents conquer the difficulties from all aspects. Meanwhile, the broad knowledge of S\&T innovative talents should include frontier knowledge because the premise of innovative activities is to know what is valuable and promising new. This determines that these S\&T innovative talents must have a system of professional knowledge, solid foundation and knowledge of related disciplines, so a systematic knowledge composed of professional knowledge, broad knowledge and solid professional basic skills is an indispensable quality of S\&T innovative activities.

\section{Innovation Ability}

Innovation ability is the impetus of the development of S\&T, so it is considered as the basic requirement of S\&T innovative talents and the natural attribute of scientific development. As mentioned above, innovative quality is one of the human beings' qualities and precious wealth to mankind. S\&T innovative talents must have good quality of innovation, creative thinking and excellent ability of innovation practice, in which stage S\&T innovative talents in the thinking activities show the originality of thinking, flexibility, quality of sharpness, rigor and foresight. On the basis of conventional research work, they deserve to have the ability to find the new ways to solve problems and to create unprecedented new achievements. To be specific, innovation ability should at least includes the ability to discover new problems and new things, the ability to put forward ideas or solutions to new problems, the ability to apply ideas and plans into practice and the ability to get innovative achievements. This requires S\&T talents to objectively reveal the essence of things and their inner links and breakthrough fixed ideas when thinking about a question. So far, the research of technology innovation ability is still at the exploratory stage.

Requirements to innovation abilities vary in different stages of S\&T innovation. Observation ability is paid much attention at the very beginning of S\&T innovation, analytical thinking ability is needed in technical design stage and self-management ability in project implementation stage. The transformation from creative ideas to achievements is completed in the process of practice. In the field of engineering, innovation ability refers to that S\&T talents could find new engineering problems in a large number of engineering practices. The new requirements of society to product, technology, process, equipment on the basis of development of economy and society as well as the new project targets on the basis of their own goals and wishes should be put forward. Thus, it is necessary to present new target, plan, ways or methods to solve these problems or requirements. Through the creative engineering practice, S\&T could solve problems, design, and research and develop new products, technologies, processes and equipment, and then realize the goal of the new project.

\section{CONCLUSIONS}

In order to cultivate outstanding S\&T innovative talents, several aspects should be highlighted.

1) The awareness of inter-discipline should be strengthened and the scope of knowledge should be broadened, so some subjects that have close relationships could be linked. This is beneficial to consolidate the foundation of innovation activities.

2) Emotional intelligence should be developed and the innovation qualities should be cultivated. Only by these methods can S\&T innovative talents possess rigorous 
scientific attitude to cope with the obstacles and barriers in S\&T innovation activities.

3) It is necessary to fully understand the drawbacks of our elementary education, scientific research and development situation and atmosphere. Only when the barriers and limits are broken can form a good scientific research and development environment, or it will affect our training of S\&T innovation talents.

\section{ACKNOWLEDGMENT}

This work was financially supported by national science foundation of China 51378365.

\section{REFERENCES}

[1] J. Liu. Requirements of technology innovation for talent quality, Science \& Technology Information, 2004, 23, 43-44.

[2] C. Cheng. Decision of technological innovation to enterprise in the future, China Intellectual Property News, 2004.

[3] Li Yang. Green building design: Wind environment of building, Shanghai: Tongji University Press, 2014.

[4] G. S. Lu, J. H. Wu, Zhang, X. L..A Review of Evaluation Studies on Innovation Ability. Research in Higher Education of Engineering, 2008, 6, 50-56.

[5] Feng Qian, Li Yang, Research on the Sustainability of Urbanization in China, Applied Mechanics and Materials, Vol. 851, pp. 664-667, 2016.

[6] Li Yang, Feng Qian, Research on the Green Wind Environment Based on Numerical Simulation, Nature Environment and Pollution Technology, Vol. 15, No. 2 (June), PP767-772, 2016.

[7] J. A. Schumpeter. The theory of economic development: An inquiry into profits, capital, credit, interest, and the business cycle. Transaction publishers, 1934.

[8] J. Schmookler. Economic sources of inventive activity. The Journal of Economic History, 1962, 22 (1), 1-20.

[9] Li Yang. Green building design: Building energy efficiency, Shanghai: Tongji University Press, 2016.

[10] N. Rosenberg. Exploring the black box: Technology, economics, and history. Cambridge University Press, 1994. 